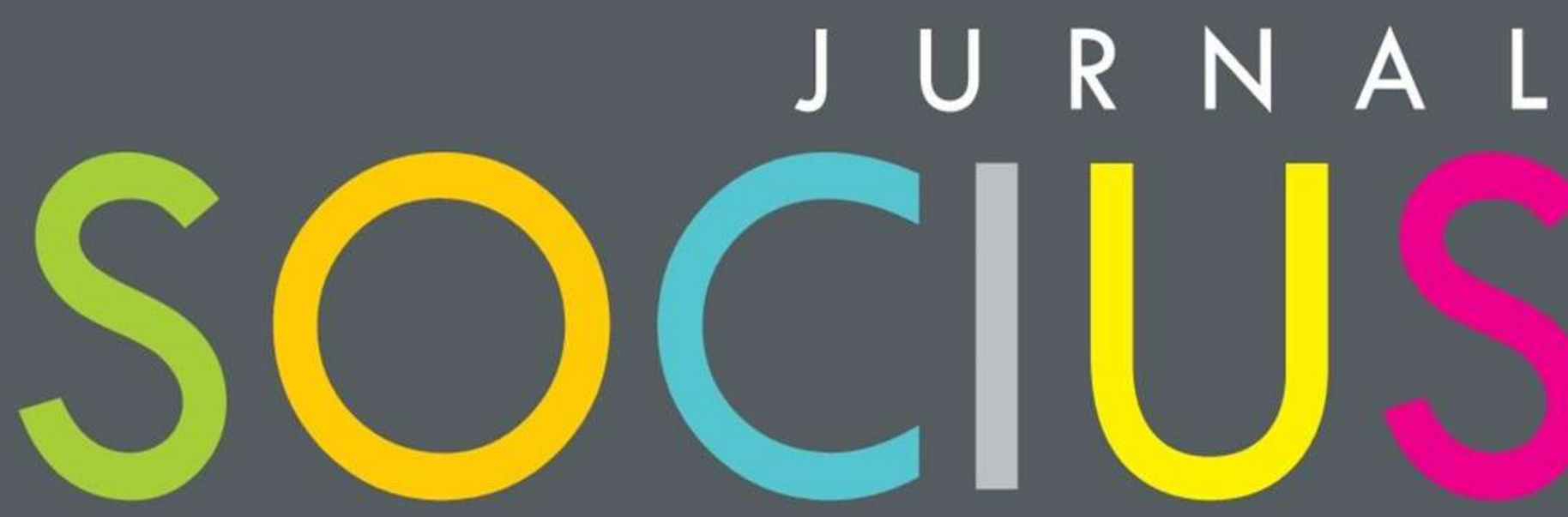

Journal of Sociology Research and Education

DITERBITKAN OLEH :

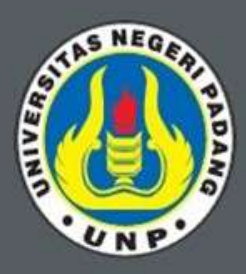

$\angle A B O R$

JURUSAN SOSIOLOGI FAKULTAS ILMU SOSIAL UNIVERSITAS NEGERI PADANG

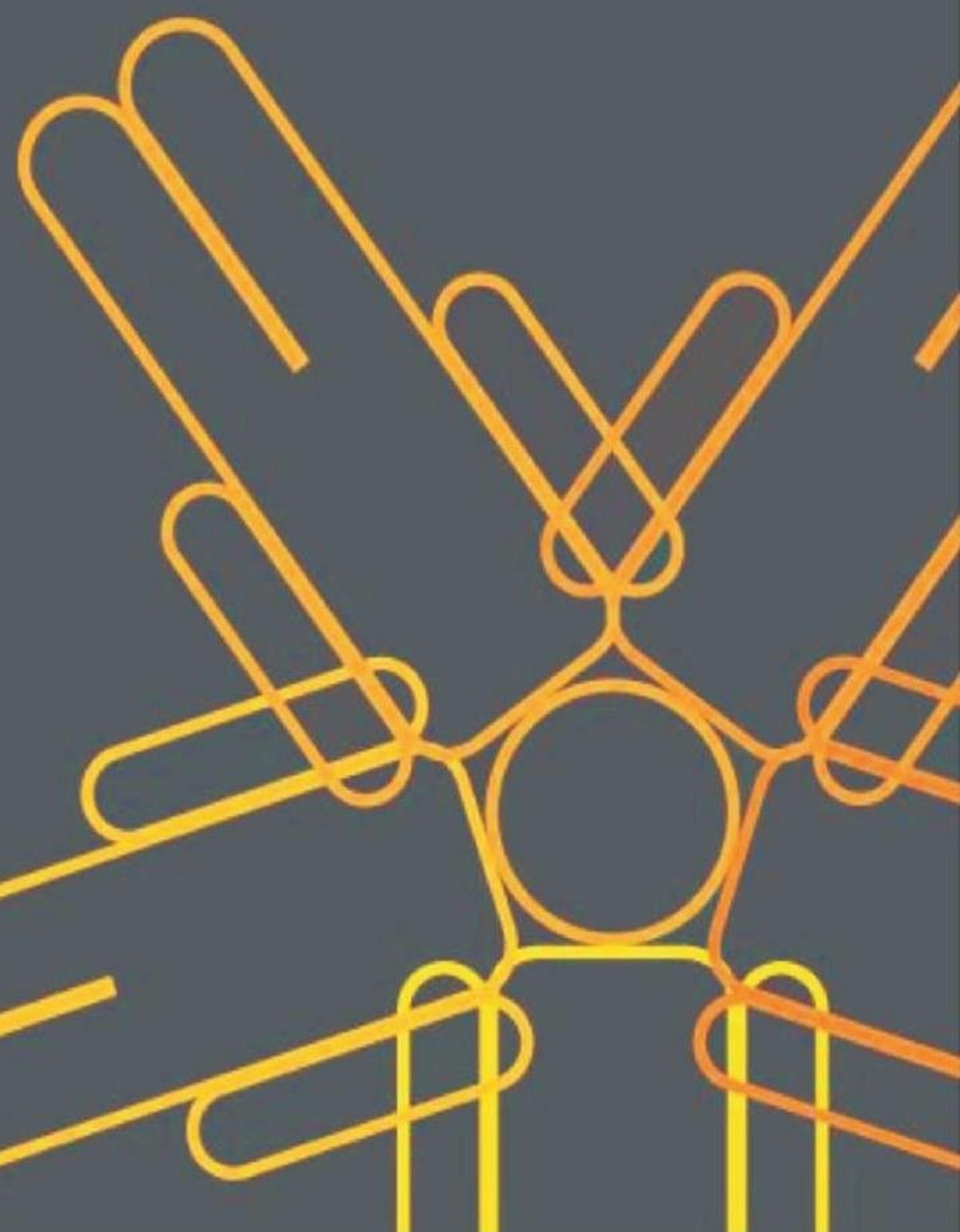




\section{SOCIUS}

Vol. 7, No. 2, Th. 2020

ISSN : 2356-4180 (cetak)

2442-8663 (online)

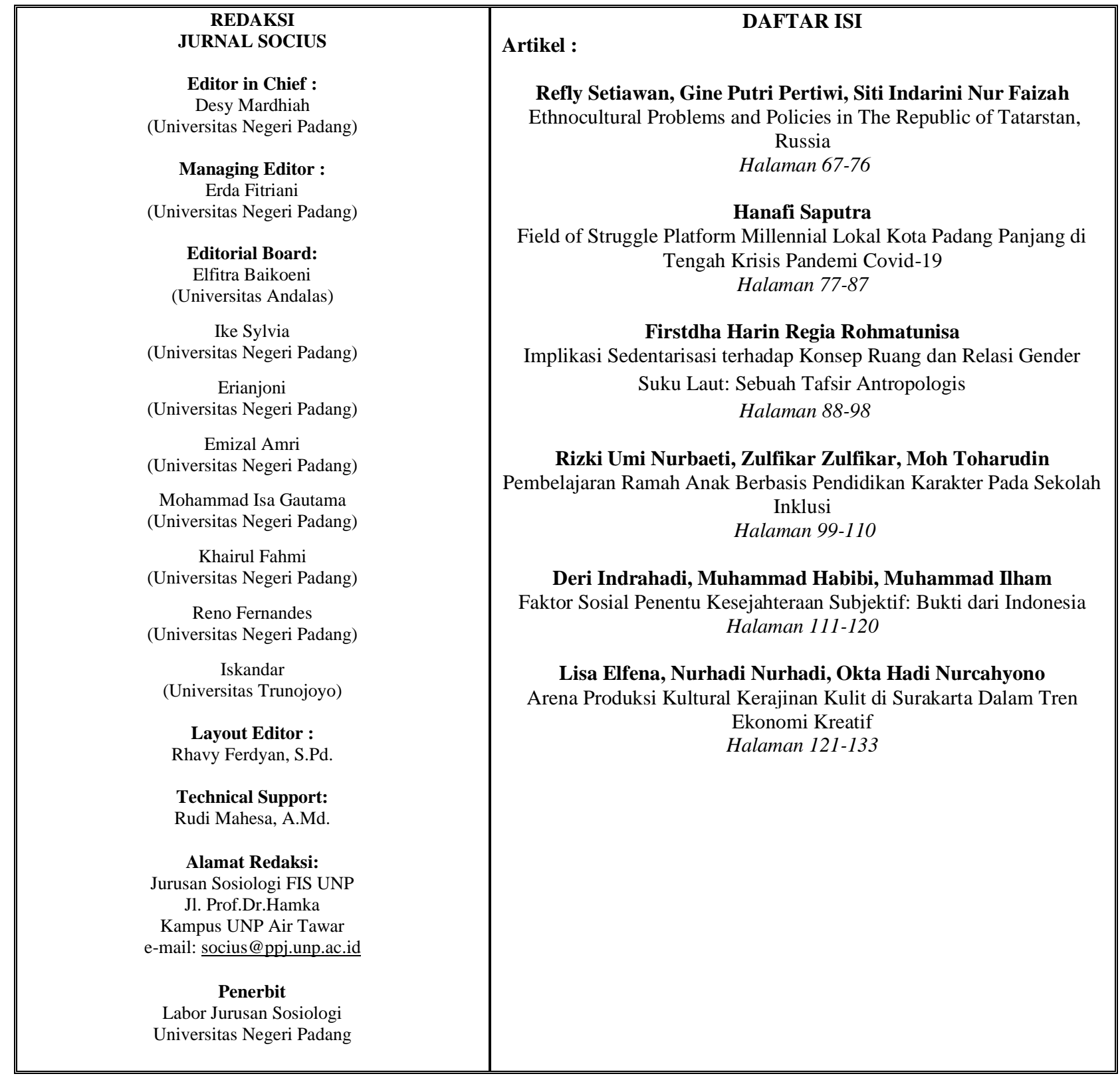




\title{
Faktor Sosial Penentu Kesejahteraan Subjektif: Bukti dari Indonesia
}

\section{Deri Indrahadi ${ }^{1}$, Muhammad Habibi ${ }^{2}$, Muhammad Ilham ${ }^{3}$}

${ }^{1}$ Universitas Negeri Yogyakarta, ${ }^{2}$ Institut Agama Islam Negeri Kerinci, ${ }^{3}$ Universitas Gajah Mada Email: dindrahadi@gmail.com

\begin{abstract}
Abstrak
Kesejahteraan subjektif merupakan permasalahan penting berbagai negara di seluruh dunia. Peneliti telah mempelajari faktor-faktor yang berpengaruh pada tingkat kesejahteraan subjektif dalam disiplin ilmu sosial, ekonomi, dan kesehatan. Penelitian ini bertujuan untuk memeriksa faktor-faktor dalam konteks sosial, ekonomi dan kesehatan yang memprediksi kesejahteraan subjektif di Indonesia. Dengan menerapkan desain penelitian potong lintang, penelitian ini menggunakan data dari Indonesia Family Life Survey dengan mengambil responden sebanyak 21,875 individu. Hasil analisis statistik menunjukkan bahwa faktor sosial ekonomi yang didalamnya mencakup; pendidikan, kepuasan kerja, kondisi kesehatan, kepercayaan sosial, dan religiusitas berkontribusi pada kesejahteraan subjektif, sedangkan status pekerjaan tidak berpengaruh signifikan. Selain itu, hasil juga menunjukkan bahwa kesejahteraan subjektif individu juga dipengaruhi oleh karakteristik demografi yang juga mencakup; jenis kelamin, status pernikahan, dan usia. Dengan demikian, temuan penelitian ini dapat digunakan untuk memahami faktor kunci penentu kesejahteraan subjektif, sekaligus dapat menjadi acuan dalam mengembangkan kebijakan oleh berbagai pihak sebagai upaya untuk meningkatkan kesejahteraan subjektif di Indonesia.

Kata Kunci: Indonesia, Kepuasan hidup, Kesejahteraan subjektif, Sosial-ekonomi
\end{abstract}

\begin{abstract}
Subjective well-being is a crucial problem in various countries around the world. Researchers have studied the factors that influence the level of subjective well-being in social, economic, and health disciplines. This study aims to examine factors in the social, economic and health context that predict subjective well-being among Indonesians. By applying a cross-sectional research design, this study uses data from the Indonesia Family Life Survey by taking 21,875 respondents. The results of statistical analysis show that socio-economic factors which include; education, job satisfaction, health conditions, social trust, and religiosity contribute on subjective well-being, while employment status has no significant effect. In addition, the results also show that the subjective well-being of individuals is also influenced by demographic characteristics which include; gender, marital status, and age. Thus, these important findings can be used to realize the key factors of subjective wellbeing and can become a reference in developing promising policies as an effort to improve subjective well-being in Indonesia.
\end{abstract}

Kata Kunci: Indonesia, Life satisfaction, Subjective well-being, Socioeconomic

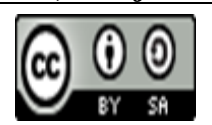

Received: October 22, 2020

Revised: December 19, 2020

Available Online: December 21, 2020

Jurnal Socius: Journal of Sociology Research and Education Vol. 7, No.2, Th. 2020 


\section{Pendahuluan}

Kesejahteraan subjektif telah menjadi topik penting dalam penelitian sejak beberapa dekade terakhir. Analisis kesejahteraan subjektif, juga disebut sebagai kepuasan hidup atau kebahagiaan, adalah topik yang relatif baru namun berkembang pesat bagi para sosiolog (Layard, 2005). Penelitian kesejahteraan dapat memberikan wawasan baru yang relevan (Frey \& Stutzer, 2002), dan studi ilmiah tentang kesejahteraan subjektif baru saja berkembang dan seharusnya menjadi topik sentral dalam ilmu sosial (Layard, 2003). Kesejahteraan subjektif didefinisikan sebagai penilaian seseorang terhadap kehidupan mereka yang berhubungan dengan kognitif dan afektif seseorang dari kehidupan mereka (Diener, 1984). Bagian afektif lebih dikenal sebagai kebahagiaan dan kognitif sebagai kepuasan hidup. Oleh karena itu, dua determinan terpenting kesejahteraan subjektif biasanya dapat diukur dan ditentukan oleh kepuasan hidup dan kebahagiaan. Kesejahteraan subjektif mengacu pada penilaian kognitif seperti kepuasan hidup, dan penilaian afektif seperti perasaan emosional positif dan negatif (Diener, Diener, \& Diener, 1995). Secara sederhana, kesejahteraan subjektif sering dikaitkan dengan bagaimana seseorang merasakan dan berpikir tentang kondisi kehidupan mereka, biasanya ditentukan dengan kepuasan hidup (Diener, 1984). Dalam berbagai literatur, defenisi kesejahteraan subjektif berfokus pada bagaimana seseorang menilai hidupnya sendiri, termasuk dalam menilai kepuasan hidup dan kebahagiaan. Berbagai defenisi telah dari kesejahteraan subjektif telah dikemukakan dalam bidang psikologi dan sosial (Dolan, Layard, \& Metcalfe, 2011). Beberapa tahun terakhir defenisi kesejahteraan subjektif juga dikemukakan oleh pembuat kebijakan dan akademisi, seperti (Stone \& Mackie, 2013)(OECD, 2013)(Waldron, 2010) telah memfokuskan perhatian pada "kondisi mental" dalam mengukur kesejahteraan subjektif. Dalam bidang ilmu psikologi, kebahagiaan dan kepuasan hidup adalah bentuk refleksi dari kesejahteraan subjektif. Kesejahteraan subjektif mengacu pada penilaian individu tentang kehidupannya sehubungan dengan penilaian kognitif, seperti kepuasan hidup dan kebahagiaan, dan evaluasi afektif seperti perasaan emosional positif dan negatif (Dolan, Peasgood, \& White, 2008)).

Penelitian sebelumnya mencatat bahwa kemajuan dan peningkatan pembangunan manusia pada suatu negara sangat terkait dengan indikator ekonomi seperti pendapatan, kemiskinan, dan pertumbuhan ekonomi. Penelitian dalam bidang ekonomi menyatakan bahwa pendapatan berhubungan signifikan dengan kesejahteraan. Pendapatan yang tinggi segaris dengan fasilitas hidup yang lebih baik, dan mengarah pada kesejahteraan. Namun dalam beberapa dekade terakhir, indikator ekonomi atau pendapatan tidak cukup untuk merepresentasikan perkembangan pembangunan manusia di suatu negara (Fleche, Clark, Layard, Powdthavee, \& Ward, 2019). Pertama kali peningkatan pendapatan tidak berbanding dengan peningkatan kebahagiaan di Amerika . Hal yang sama juga ditemukan oleh Diener dan Seligman (2004) bahwa meskipun ekonomi terus tumbuh pesat dalam beberapa dekade, namun pertumbuhan tersebut tidak sejalan dengan peningkatan kualitas hidup (Diener \& Seligman, 2004). Para ahli kemudian mulai menyadari bahwa pentingnya mengukur kesejahteraan dengan cara yang lebih baik, yang selama ini hanya diukur hanya berdasarkan pendapatan (Forgeard, M. J., Jayawickreme, Kern, \& Seligman, 2011).

Pengukuran dan penilaian kesejahteraan subjektif sangat penting untuk menggambarkan tren kesejahteraan individu dari waktu ke waktu, menentukan bagaimana mendesain kebijakan, terutama dalam kebijakan ekonomi (Dolan et al., 2011) (Dolan, 2014). Peneliti sosial dan psikologi sepakat bahwa indikator penting dalam mengukur kesejahteraan subjektif adalah kebahagiaan, kepuasan hidup, dan penilaian emosional. Dalam perkembangan terkini, peneliti mengidentifkasi faktor sosial ekonomi yang yang mempengaruhi kesejahteraan subjekif. Pendapatan, pekerjaan, kepemilikan rumah, kondisi kesehatan, pendidikan dan keterampilan, relasi sosial, partisipasi pemerintahan, kualitas lingkungan, dan keamanan personal adalah

Jurnal Socins: Journal of Sociology Research and Education Vol. 7, No.2, Th. 2020 
varibel-varibel yang digunakan dalam beberapa penelitian. Variabel-varibel tersebut juga digunakan OECD dalam mengukur kesejahteraan subjektif (Fleche, Simith, \& Sorsa, 2012). Pengukuran kesejahteraan subjektif dalam beberapa penelitian menggunakan indikator kebahagiaan. Namun penelitian lain yang mengukur kesejahteraan subjektif difokuskan pada kepuasan hidup (Donovan, Halpern, \& Sargeant, 2002)(Waldron, 2010). Penilaian kesejahteraan di Indonesia yang dilakukan Badan Pusat Statistik (BPS) menggunakan istilah dan ukuran kebahagiaan. Ukuran kebahagiaan yang digunakan BPS teridiri dari tiga dimensi. Kepuasan hidup adalah dimensi utama yang digunakan untuk ukuran kebahagiaan (BPS, n.d.). Terdapat perbedaan istilah yang digunakan dalam penelitian untuk mengukur kesejahteraan subjektif, umumnya peneliti menggunakan istilah kebahagian, kualitas hidup, kepuasan hidup. Namun beberapa peneliti lainnya tidak mempermasalahkan perbedaan istilah dan pengukuran kesejahteraan subjektif. Peneliti lebih cenderung menggunakan istilah dan pengukuran tersebut secara bergantian.

Penelitian kesejahteraan subjektif di Indonesia menjadi topik yang menarik dikalangan peneliti. Penelitian sebelumnya telah mengukur keejahteraan subjektif dengan data Indonesia Family Life Survey gelombang ke-empat pada tahun 2007 (Sohn, 2010). Selain itu, penelitian dengan menggunakan data BPS tahun 2017 juga telah mengukur berbagai faktor yang mempengaruhi kesejahteraan subjektif yang difokuskan pada masyarakat kota. Penelitian tersebut mengukur kesejahteraan subjektif dengan indikator kebahagiaan. Sementara penelitian ini menggunakan data terbaru dari IFLS 2015 dan mengambil keseluruhan responden di kota maupun desa. Data dan ruang lingkup kajian ini menjadi kebaruan dalam penelitian ini, yang dapat memberikan kontribusi pada kajian penentuan kesejahteraan subjektif masyarakat Indonesia yang diukur dari berbagai faktor seperti faktor sosial, ekonomi, kesehatan dan karakteristik demografi. Berdasarkan hal tersebut, penelitian ini bertujuan untuk menganalis bagaimana faktor sosial, ekonomi, kesehatan, dan karakteristik demografi lainnya menentukan kesejahteraan subjektif (kepuasan hidup) masyarakat Indonesia.

\section{Metode Penelitian}

\section{Desain dan Data Penelitian}

Penelitian ini menggunakan desain potong lintang. Data dalam penelitian ini diperoleh dari Indonesia Family Life Survey (IFLS). IFLS merupakan survei rumah tangga di Indonesia yang menyediakan data longitudinal yang merepresentasikan $80 \%$ populasi dari 13 provinsi di seluruh Indonesia. Penelitian ini menggunakan data IFLS ke-5 tahun 2015 dengan total keseluruhan 50.148 responden individu dan 16.204 rumah tangga (Herningtyas et al., 2018). Data IFLS diperoleh melalui survei dan kuisioner tatap muka. Dalam penelitian ini, peneliti membatasi sampel di provinsi-provinsi di Sumatera dan responden dengan usia di atas 15 tahun yang menyelesaikan tanggapan kuisioner kesejahteraan subjektif dan berbagai aspek sosial, ekonomi, dan kesehatan. Penelitan ini menghasilkan 21,875 sampel individu.

\section{Pengukuran}

Kesejahteraan subjektif diukur dengan kepuasan hidup. Kami menggunakan kuisioner dalam survei yang menanyakan "Seberapa puas Ibuk/Bapak/Saudara dengan kehidupan saat ini?" Tanggapan dicatat dalam lima-kategori skala ordinal yang berkisar dari 0 sampai $4(0=$ amat sangat puas, $1=$ sangat puas, $2=$ agak puas, $3=$ tidak puas, 4 amat tidak puas), tanggapan ini di kode ulang dengan membalikkan angka terkecil menjadi yang paling besar.

Tingkat pendidikan diukur dengan 4 kategori berdasarkan standar pendidikan formal di Indonesia dari Sekolah Dasar, Sekolah Menengah Pertama, Sekolah Menengah Atas, dan Perguruan Tinggi. Status pekerjaan dibedakan secara dikotomi bekerja dan tidak bekerja. 
Kepuasan bekerja diukur dengan pertanyaan "Apakah Bapak/Ibuk/Saudara puas dengan pekerjaan yang dimiliki sekarang?" Tanggapan dicatat dengan empat-kategori dengan skala ordinal $(3=$ sangat puas, $2=$ puas, $1=$ tidak puas, $0=$ sangat tidak puas). Kondisi kesehatan diukur dengan pertanyaan "Secara umum, bagaimana kondisi kesehatan Bapak/Ibuk/Saudara saat ini?" Tanggapan berkisar dari ( $3=$ Sehat sekali, $2=$ cukup sehat, $1=$ kurang sehat, $0=$ tidak sehat). Kepercayaan sosial diukur dengan pertanyaan "Bapak/Ibuk/Saudara bersedia membantu orang lain jika dibutuhkan" Tanggapan berkisar antara ( $3=$ sangat setuju, $2=$ setuju, $1=$ tidak setuju, $0=$ sangat tidak setuju). Religiusitas diukur dengan pertanyaan "Seberapa taatkan Bapak/Ibuk/Saudara dalam beragama?" Tanggapan berkisar dari $(3=$ sangat taat, $2=$ taat, $1=$ agak taat, $0=$ tidak taat).

Variabel kontrol dalam penelitian ini adalah jenis kelamin, usia, dan status perkawinan. Jenis kelamin dibedakan secara dikotomi perempuan dan laki-laki. Usia dibagi dalam 4 kategori $(15-24,25-34,35-44,45-54$, lebih dari 55). Status perkawinan dibedakan secara dikotomi menikah dan tidak menikah.

\section{Metode Analisis Data}

Pendekatan kuantitatif dengan analisis data sekunder diterapkan dalam penelitian ini dari data yang diperoleh dari IFLS. Penelitian ini mengambil hipotesis bahwa pendidikan, status pekerjaan, kepuasan kerja, kondisi kesehatan, kepercayaan sosial, religiusitas, jenis kelamin, status pernikahan, dan usia mempengaruhi kesejahteraan subjektif. Tiga langkah analisis statistik diterapkan untuk membuktikan hipotesis penelitian ini. Pertama, statistik deskriptif variabel dependen (kesejahteraan subjektif) dan variabel independen ditampilkan, termasuk jumlah responden, nilai rata-rata, standar deviasi, seluruh variabel penelitian. Kedua, analisis korelasi untuk mengetahui arah hubungan masing-masing variabel dengan kesejahteraan subjektif dengan analisis korelasi Pearson. Ketiga, regresi linier berganda diterapkan untuk menguji pengaruh seluruh variabel bebas terhadap variabel terikat pada taraf signifikansi 0,05 . Analisis regresi linier berganda juga diterapkan untuk membuktikan hipotesis penelitian yang diajukan. Kedua analisis statistik tersebut dilakukan dengan $R$ Studio Statistics Software.

\section{Hasil dan Pembahasan}

Penelitian ini bertujuan untuk menyelidiki berbagai faktor sosial penentu kesejahteraan subjektif dengan ukuran kepuasan hidup yang dilaporkan individu di Indonesia dengan menggunakan data nasional dari survei IFLS terbaru 2015. Pertama, kami menampilkan hasil analisis deskriptif termasuk nilai rata-rata dan standar deviasi seluruh variabel di tabel I.

Tabel I. Statistik Deskriptif Seluruh Variabel Penelitian

\begin{tabular}{lccc}
\hline Variabel & Partisipan & Rata-Rata & Standar Deviasi \\
\hline Kepuasan hidup & 21,875 & 2,30 & 0,80 \\
\hline Pendidikan & 21,875 & 2,30 & 1,08 \\
\hline Status pekerjaan & 21,875 & 0,98 & 0,12 \\
\hline Kepuasan kerja & 21,875 & 1,93 & 0,57 \\
\hline Kondisi kesehatan & 21,875 & 1,97 & 0,64 \\
\hline Kepercayaan sosial & 21,875 & 2,27 & 0,46 \\
\hline Religiusitas & 21,875 & 1,90 & 0,69 \\
\hline Jenis kelamin & 21,875 & 0,43 & 0,49 \\
\hline Status pernikahan & 21,875 & 0,77 & 0,41 \\
\hline Usia & 21,875 & 37,88 & 12,99
\end{tabular}

Sumber: IFLS 2015 dan diolah peneliti 
Berdasarkan hasil analisis deskriptif pada tabel I, secara keseluruhan responden melaporkan tingkat kesejahteraan subjektif pada kisaran 2 sampai 3, yaitu pada kategori "sangat puas", dan hanya sekitar 14 persen dari seluruh responden yang melaporkan kesejahteraan subjektif pada tingkat "tidak puas dan sangat tidak puas". Rata-rata tingkat pendidikan adalah Sekolah Menangah Atas. sebagian besar responden juga melaporkan bahwa mereka puas dengan pekerjaannya. Rata-rata kondisi kesehatan yang dilaporkan responden adalah 1,97 atau dalam kondisi sehat. Responden menunjukkan tingkat kepercayaan sosial yang sangat tinggi. Selain itu, rata-rata responden dalam penelitian ini taat dalam beragama atau religius.

Tabel II. Analisis Korelasi Pearsons

\begin{tabular}{lcc}
\hline Variabel & Partisipan & Korelasi Bivariat \\
\hline Kepuasan hidup & 21,875 & $1,00^{*}$ \\
\hline Pendidikan & 21,875 & $0,09^{*}$ \\
\hline Status pekerjaan & 21,875 & $0,03^{*}$ \\
\hline Kepuasan kerja & 21,875 & $0,31^{*}$ \\
\hline Kondisi kesehatan & 21,875 & $0,15^{*}$ \\
\hline Kepercayaan sosial & 21,875 & $0,05^{*}$ \\
\hline Religiusitas & 21,875 & $0,11^{*}$ \\
\hline Jenis kelamin & 21,875 & $0,05^{*}$ \\
\hline Status pernikahan & 21,875 & $0,00^{*}$ \\
\hline Usia & 21,875 & $-0,08^{*}$ \\
\hline
\end{tabular}

Sumber: IFLS 2015 dan diolah peneliti

Catatan: * taraf signifikansi 0,05.

Selanjutnya kami menampilkan hasil korelasi bivariat sebelum menampilkan hasil analisis multivariat dengan regresi berganda. Hasil korelasi Pearson ditampilkan di tabel II, hasil analisis menunjukkan hubungan positif antara seluruh variabel independen dengan kesejahteraan subjektif. Diantara variabel kontrol, hanya variabel usia yang berkorelasi negatif dengan kesejahteraan subjektif.

Tabel III. Analisis Regresi Linier Berganda

\begin{tabular}{lccccc} 
Kepuasan hidup & Estimate & $\begin{array}{c}\text { Std. } \\
\text { error }\end{array}$ & $\mathbf{T}$ & $\mathbf{P}>\mathbf{t}$ & (95\% Coef. Interval) \\
\hline Cons & 0,914 & 0,54 & 16,75 & $0,000^{*}$ & $0,08-1,02$ \\
\hline Pendidikan & 0,059 & 0,00 & 11,99 & $0,000^{*}$ & $0,04-0,06$ \\
\hline Status pekerjaan & 0,005 & 0,03 & 0,13 & 0,898 & $0,39-0,42$ \\
\hline Kepuasan kerja & 0,407 & 0,00 & 45,09 & $0,000^{*}$ & $0,11-0,14$ \\
\hline Kondisi kesehatan & 0,128 & 0,00 & 15,97 & $0,000^{*}$ & $0,01-0,05$ \\
\hline Kepercayaan sosial & 0,036 & 0,01 & 3,30 & $0,001^{*}$ & $0,08-0,11$ \\
\hline Religiusitas & 0,101 & 0,00 & 13,35 & $0,000^{*}$ & $0,04-0,09$ \\
\hline Perempuan & 0,070 & 0,01 & 6,72 & $0,000^{*}$ & $0,01-0,06$ \\
\hline Menikah & 0,035 & 0,01 & 2,81 & $0,005^{*}$ & $-0,05--0,03$ \\
\hline Usia & $-0,046$ & 0,00 & $-10,12$ & $0.000^{*}$ & $0,80-1.02$ \\
\hline Jumlah responden & & & & & 21,875 \\
\hline $\mathrm{R}^{2}$ & & & & & 0,1337 \\
\hline Prob > F & & & & &
\end{tabular}

Sumber: IFLS 2015 dan diolah peneliti

Catatan: * taraf signifikansi $1 \%$ 
Tabel III menampilkan hasil analisis multivariat yang menunjukkan bahwa seluruh variabel penelitian memprediksi kesejahteraan subjektif sebesar 14 persen secara simultan. Hasil ini mendukung hipotesis bahwa pendidikan, status pekerjaan, kepuasan kerja, kondisi kesehatan, kepercayaan sosial, religiusitas, jenis kelamin, status pernikahan, dan usia secara signifikan mempengaruhi kesejahteraan subjektif diantara populasi di Indonesia. Temuan penelitian ini mengkonfirmasi sebagian besar hasil penelitian sebelumnya yang membuktikan bahwa terdapat pengaruh berbagai faktor sosial, ekonomi, dan kesehatan terhadap kesejahteraan subjektif di negara maju dan berkembang.

Berbagai penjelaskan dapat mengungkapkan bagaimana pengaruh faktor sosial, ekonomi, kesehatan, dan karakteristik demografi terhadap kesejahteraan subjektif di antara orang Indonesia. Pertama, temuan kami menunjukkan bahwa pendidikan sebagai indikator utama status sosial ekonomi sangat menentukan kepuasan hidup individu. Temuan ini segaris dengan temuan penelitian sebelumnya (Chen, 2012). Tingkat pendidikan yang tinggi dapat meningkatkan kepuasan hidup seseorang, hal ini dikarenakan dengan pendidikan yang tinggi, seseorang memiliki kesempatan untuk mendapat pekerjaan yang biak. Semakin tinggi tingkat pendidikan seseorang berbanding dengan kepuasan hidup yang tinggi. Sebaliknya, seseorang yang berpendidikan rendah merasa kurang puas dengan kehidupannya. Dalam penelitian ini, tingkat pendidikan membuat perbedaan kesejahteraan subjektif pada setiap individu. Penelitian sebelumnya menyebutkan bahwa pendidikan akan menurunkan kemungkinan seseorang jatuh ke dalam kemiskinan (Ferro Luzzi, Fluckiger, \& Weber, 2008), karena pendidikan dapat memberikan lebih banyak kemungkinan untuk memiliki pekerjaan dan memiliki pendapatan yang tinggi. Pada dasarnya, hubungan antara pendidikan dan kesejahteraan terkadang bisa positif dan negatif lainnya. Biasanya, pendidikan dapat memberikan akses yang lebih mudah ke pasar kerja, gaji yang lebih tinggi, kreativitas yang lebih besar dan menimbulkan rasa kepuasan dalam kehidupan seseorang. Pada dasarnya hasil temuan penelitian konsisten menyatakan hubungan yang kuat antara pendidikan yang tinggi dengan kesejahteraan subjektif yang tinggi. Namun di sisi lain, hasil penelitian juga mengungkapkan bahwa banyak orang yang berpendidikan (perguruan tinggi ke atas) berhubungan dengan kesejahteraan yang rendah. Hal ini terjadi karena tingkat pendidikan yang tinggi menimbulkan ekspektasi yang besar dan timbul perasaan kecewa serta dapat menurunkan tingkat kepuasan hidup seseorang (Schimmel, 2009).

Kemudian, status pekerjaan dan kepuasan kerja termasuk dalam analisis penelitian ini. Temuan penelitian ini mengungkapkan bahwa status pekerjaan tidak mempengaruhi kepuasan hidup seseorang, tetapi kepuasan kerja berpengaruh pada kepuasan hidup secara signifikan. Temuan ini berarti tidak ada perbedaan diantara orang yang berkerja pada kepuasan hidup yang dilaporkan, tetapi orang yang puas dengan pekerjaannya akan meningkatkan kepuasan hidupnya. Nandini and Afiatno (2020), mencatat bahwa kepuasan kerja berpengaruh positif terhadap kesejahteraan subjektif yang diukur dengan kebahagiaan. Temuan ini segaris dengan sebagian besar hasil penelitian sebelumnya (Frey \& Stutzer, 2018). Temuan ini kontra dengan beberapa temuan penelitian sebelumnya yang menyatakan bahwa ketenagakerjaan dan kesejahteraan subjektif sangat terkait satu sama lain. Penganggur di hampir semua negara jauh lebih tidak bahagia daripada mereka yang bekerja (Frey \& Stutzer, 2002). Pengangguran lebih berkorelasi kuat dengan tidak adanya kesejahteraan positif daripada dengan adanya gejala tekanan psikologis (Huppert \& Whittington, 2003).

Peneliti bidang kesehatan telah menjelaskan hubungan antara kondisi kesehatan seseorang dengan kesejahteraan subjektif. Temuan penelitian ini menunjukkan bahwa kondisi kesehatan berpengaruh signifikan terhadap kepuasan hidup seseorang. Temuan ini mengkonfirmasi hasil penelitian sebelumnya (Frijters, Haisken-DeNew, \& Shields, 2004). Orang dengan kondisi kesehatan yang baik akan merasa puas dengan kehidupannya, hal ini disebabkan individu yang sehat tidak memiliki kendala dalam melakukan aktivitas dan 
pekerjaan sehari-hari (Frey \& Stutzer, 2002). Orang yang menikmati kondisi kesehatan yang baik dalam penelitian ini menunjukkan kesejahteraan yang positif dan kesehatan tampaknya menjadi salah satu faktor terkuat yang mempengaruhi kesejahteraan subjektif. Individu yang merasa bahagia dan puas dengan kehidupannya mereka akan lebih percaya diri, mengatasi masalah kesehatan dengan lebih baik dan hidup lebih baik daripada orang yang merasa kurang bahagia (Schimmel, 2009).

Sebagian besar orang Indonesia religius. Hasil penelitian ini mengungkapkan bahwa religiusitas mempengaruhi kepuasan hidup seseorang. Pengaruh signifikan antara religiusitas dengan kepuasan hidup mengkonfirmasi temuan penelitian sebelumnya (Koenig, 1997)(AbdelKhalek, 2006). Temuan ini berarti bahwa semakin taat seseorang dalam beragama, maka seseorang akan lebih merasa puas dengan hidupnya. Berbagai studi empiris telah menunjukkan bahwa orang-orang yang taat beragama dan berkomitmen pada keyakinan dan kepercayaan agamanya cenderung merasakan kesehatan mental maupun fisik yang lebih baik. Temuan ini menjelaskan bahwa secara umum bahwa agama memainkan peran sentral dan dan penting dalam kehidupan masyarakat Indonesia.

Selain itu, temuan penelitian ini konsisten dengan beberapa hasil penelitian bidang psikologi yang menyatakan bahwa pentingnya kepercayaan sosial untuk kesejahteraan subjektif. Integrasi sosial yang diukur dengan berbagai dimensi, termasuk interkasi dengan tetangga, dan keperyaaan sosial dengan tetangga berhubungan dengan peningkatan kesejahteraan subjektif (Appau, Churchill, \& Farrell, 2020). Temuan ini bermakna bahwa kesejahteraan subjektif tidak hanya dipengaruhi oleh kondisi internal, namun juga kondisi eksternal seperti kepercayaan sosial juga mempengaruhinya. Integasi sosial merupakan aspek diluar individu yang berpengaruh pada kebahagiaan (Nandini \& Afiatno, 2020). Temuan ini melihat pentingnya peran integrasi sosial dalam menentukan kesejahteraan subjektif. Sebaliknya, penelitian sebelumnya membuktikan bahwa isolasi sosial berkontribusi besar terhadap kesehatan mental yang buruk,sehingga sangat penting untuk memahami hubungan antara kepercayaan sosial terhadap kesejahteraan subjektif. Temuan ini mengindikasikan bahwa pentingnya berinteraksi dengan tetangga, memiliki rasa percaya kepada orang lain sebagai faktor yang berkontribusi pada kesejahteraan.

Temuan lain penelitian ini menunjukkan bahwa berbagai karakteristik demografi seseorang juga berhubungan dengan kepuasan hidup. Perbedaan jenis kelamin berhubungan dengan kepuasan hidup. Hasil analisis menunjukkan bahwa perempuan lebih puas dengan hidupnya dibandingkan dengan laki-laki. Temuan ini mendukung hasil penelitian sebelumnya di beberapa negara OECD yang menyatakan bahwa perempuan berhubungan dengan tingkat kepuasan hidup yang tinggi (Boarini, Comola, Smith, Manchin, \& De Keulenear, 2012). Meskipun demikian, penelitian sebelumnya telah mengindikasikan bahwa temuan empiris mengenai peran gender dan perbedaan gender dalam kesejahteraan tidak konsisten (Cummins, 2014). Meskipun beberapa penelitian telah menunjukkan bahwa perempuan lebih bahagian dari pada laki-laki (Fujita, Diener, \& Sandvik, 1991), penelitian lain telah melaporkan bahwa yang terjadi adalah sebaliknya (Stevenson \& Wolfers, 2009). Bahkan ada penelitian yang menunjukkan tidak ada perbedaan jenis kelamin yang signifikan terhadap kesejahteraan subjektif (Okun \& George, 1984). Kesimpulan yang tidak konsisten dan bertentangan ini dapat dijelaskan sebagian dengan perbedaan dalam konseptualisasi kesejahteraan subjektif dalam berbagai penelitian (misalnya, pengaruh positif, pengaruh negatif, dan kepuasan hidup; Diener, Lucas, \& Oishi, 2002). Hal ini mungkin karena perbedaan gender dipengaruhi oleh berbagai faktor struktural dan sosial budaya (Batz \& Tay, 2018). Akibatnya, temuan bergantung pada waktu saat studi dilakukan dan wilayah yang menjadi perhatian studi. Dengan pemikiran ini, berdasarkan sampel nasional yang mewakili besar yang mencakup periode waktu tertentu, perempuan Indonesia mengevaluasi kehidupan mereka secara lebih positif daripada laki-laki. 
Penelitian ini juga mengungkapkan bahwa status pernikahan berhubungan dengan kepuasan hidup. Hasil analisis menunjukkan bahwa orang yang menikah lebih puas dengan hidupnya dibandingkan dengan orang yang tidak menikah (belum menikah, cerai hidup, cerai mati, berpisah). Temuan ini mengkonfirmasi temuan penelitian sebelumnya (DeLongis, Folkman, \& Lazarus, 1988). Penelitian sebelumnya telah menunjukkan bahwa status pernikahan dan kebahagiaan terkait bahwa orang yang menikah lebih bahagia daripada yang belum menikah, dan hubungan ini dimoderasi oleh jenis kelamin. Secara lebih spesifik, wanita yang sudah menikah lebih bahagia daripada pria menikah dan orang yang belum menikah pada. Mengapa? Mungkin karena norma budayanya adalah perempuan harus menemukan kebahagiaan di rumah, sedangkan laki-laki menemukan kepuasan di tempat kerja. Penelitian sebelumnya menyebutkan bahwa yang mengaku sangat bahagia kebanyakan adalah wanita yang sudah menikah. Temuan ini konsisten dengan literatur sebelumnya yang menyatakan hubungan yang kuat antara status pernikahan dengan kepuasan hidup. Banyak bukti yang menunjukkan bahwa menyendiri (tidak menikah, berpisah) lebih buruk daripada menikah dalam menilai kesejahteraan hidup (Dolan, 2014).

Selain itu, usia juga ditemukan berpengaruh signifikan terhadap kepuasan hidup. Temuan ini menunjukkan bahwa peningkatan usia menurunkan kepuasan hidup seseorang (Boarini et al., 2012). Menyatakan bahwa usia memiliki hubungan dengan kepuasan hidup. Ia menambahkan bahwa pekerjaan dan pendapatan mempunyai pengaruh yang besar pada kepuasan hidup pada usia bekerja. Hasil penelitian menyebutkan bahwa usia lansia sering mengalami penurunan kapasitas fungsionalnya, hal ini dikarenakan sejak usia 65 dan seterusnya, seseorang sangat rentan dengan penurunan kualitas kesehatan. Oleh karena itu, peningkatan usia atau memasuki usia lanjut memiliki kemungkinan yang besar dalam mengalami penurunan kapasitas fungsional yang diikuti dengan tingkat kesejahteraan emosional yang menurun.

\section{Simpulan}

Temuan penelitian ini membuktikan bahwa faktor sosial ekonomi yang di dalamnya termasuk pendidikan, status pekerjaan dan kepuasan bekerja berpengaruh signifikan terhadap kesejahteraan subjektif di Indonesia. Selain itu, kondisi kesehatan individu juga menunjukkan pengaruh yang signifikan terhadap kesejahteraan subjektif. Temuan penelitian ini juga membuktikan bahwa kepercayaan sosial (social trust) dan religiusitas mempengaruhi kesejahteraan subjektif individu. Karakteristik demografi yang termasuk jenis kelamin, status pernikahan dan usia juga berpengaruh signifikan terhadap kesejahteraan subjektif. Pendidikan, kesehatan, dan aspek sosial lainnya adalah indikator yang harus diperhatikan oleh masyarakat dan pemerintah karena mereka menjadi faktor yang penting dalam menentukan kesejahteraan subjektif di Indonesia.

Penelitian ini memiliki beberapa keterbatasan, yang bisa menjadi celah bagi penelitian berikutnya, diantaranya pertama, penelitian ini menggunakan desain potong lintang dengan mengambil data survei pada satu periode tertentu, sehingga temuan penelitian ini tidak dapat menggambarkan tren kesejahteraan subjektif di Indonesia dan bagaimana hubungan timbal balik antara kesejahteraan subjektif dengan variabel-variabel penentu. Penelitian masa depan di harapkan dapat menganalisis kesejahteraan subjektif dengan data penel sehingga dapat menggambarkan tren kesejahteraan subjektif dan dapat menganalisis hubungan timbal balik antara kesejahteraan subjektif dan variabel-variabel penentu. Kedua, indikator sosial, ekonomi yang digunakan belum dapat menggambarkan kondisi sosial, ekonomi seseorang secara kompleks. Pendapatan merupakan ukuran sosial, ekonomi yang banyak digunakan dalam penelitian, variabel pendapatan tidak dimasukkan dalam analisis penelitian ini disebabkan oleh ketersediaan data dari IFLS. Penelitian mendatang diharapkan dapat menggunakan ukuran 
sosial, ekonomi yang lebih dengan memasukkan variabel pendapatan sehingga dapat mengukur kondisi sosial, ekonomi dengan lebih tepat.

\section{Rujukan}

Abdel-Khalek, A. M. (2006). Happiness, health, and religiosity: Significant relations. Mental Health, Religion dan Culture, 9(1), 85-97.

Appau, S., Churchill, S. A., \& Farrell, L. (2020). Wellbeing among Older People: An Introduction. Singapore: Palgrave Macmillan.

Batz, C., \& Tay, L. (2018). Gender differences in subjective wellbeing. Handbook of wellbeing. Salt Lake City. UT: DEF Publishers.

Boarini, R., Comola, M., Smith, C., Manchin, R., \& De Keulenear, F. (2012). What makes for a better life?: The determinants of subjective well-being in OECD countries-Evidence from the Gallup World Poll.

BPS. (n.d.). Indeks kebahagiaan 2017. Jakarta: Badan Pusat Statistik.

Chen, W. (2012). How Education Enhances Happiness: Comparison of Mediating Factors in Four East Asian Countries. Social Indicators Research, 106(1), 117-131.

Cummins, R. A. (2014). Gender dimensions of life quality for adults in Australia. In E. Eckermann (Ed.), Gender, lifespan and quality of life: An international perspective. Dordrecht, the Netherlands: Springer.

DeLongis, A., Folkman, S., \& Lazarus, R. S. (1988). The Impact of Daily Stress on Health and Mood: Psychological and Social Resources as Mediators. Journal of Personality and Social Psychology, 54(3), 486-495.

Diener, E. (1984). Subjective well-being. Psychological Bulletin, 9(1), 542-575.

Diener, E., Diener, M., \& Diener, C. (1995). Factors predicting th subjective well-being of nations. Journal of Personality and Social Psychology, 69(5), 851-864.

Diener, E., \& Seligman, M. E. P. (2004). Beyond Money: Toward an Economy of Well-Being. Psychological Science in the Public Interest, 5(1), 1-31.

Dolan, P. (2014). Happiness by design: Change what you do, not how you think. New York: Penguin.

Dolan, P., Layard, R., \& Metcalfe, R. (2011). Measuring subjective well-being for public policy. London: Office for National Statistics.

Dolan, P., Peasgood, T., \& White, M. P. (2008). Do we really know what makes us happy? A review of the economic literature on factors associated with subjective well-being. Journal of Economic Psychology, 29(1), 94-122.

Donovan, N., Halpern, D., \& Sargeant, R. (2002). Life satisfaction: The state of knowledge and implications for government. London: Cabinet Office, Strategy Unit.

Ferro Luzzi, G., Fluckiger, Y., \& Weber, S. (2008). A cluster analysis of multidimensional poverty in Switzerland', in Kakwani, N. and Silber, J. (Eds.): Quantitative Approaches to Multidimensional Poverty Measurement. New York: Palgrave Macmillan.

Fleche, S., Clark, A. E., Layard, R., Powdthavee, N., \& Ward, G. (2019). The origins of happiness: the science of well-being over the life course. New England: Princeton University Press.

Fleche, S., Simith, C., \& Sorsa, P. (2012). Exploring determinant of subjective well-being in OECD countries: evidence from the World Value Survey.

Forgeard, M. J., Jayawickreme, E., Kern, M. L., \& Seligman, M. E. (2011). Doing the right thing: Measuring wellbeing for public policy. International journal of wellbeing, 1(1), $1-12$.

Frey, B. S., \& Stutzer, A. (2002). What can economists learn from happiness research? Journal of Economic Literature, 40(2), 402-435. 
Frey, B. S., \& Stutzer, A. (2018). Economics of Happiness. New York: Springer.

Frijters, P., Haisken-DeNew, J. P., \& Shields, M. A. (2004). Investigating the patterns and determinants of life satisfaction in Germany following reunification. . . Journal of Human Resources, 39(3), 649-674.

Fujita, F., Diener, E., \& Sandvik, E. (1991). Gender differences in negative affect and wellbeing: The case for emotional intensity. Journal of Personality and Social Psychology, 61(3), 427-434.

Herningtyas, E. H., Hu, P., Edenfield, M., Strauss, J., Crimmins, E., Witoelar, W., \& Sikoki, B. (2018). IFLS Wave 5 Dried Blood Spot Data User Guide. New England: St Monica RAND.

Huppert, F. ., \& Whittington, J. . (2003). Evidence for the independence of positive and negative wellbeing: implications for quality of life assessment. British Journal of Health Psychology, 8(1), 107-122.

Koenig, H. G. (1997). Is religion good for your health? The effects of religion on physical and mental health. New York: Haworth Pres.

Layard, R. (2003). Happiness: Has Social Science a Clue?

Layard, R. (2005). Happiness - Lessons from a New Science. New York: Penguin.

Nandini, D., \& Afiatno, B. E. (2020). The Determinants of Happiness: Empirical Evidence of Java Island. Jurnal Ekonika: Jurnal Ekonomi Universitas Kadiri, 5(2), 123-139.

OECD. (2013). OECD guidelines on measuring subjective well-being. New England: OECD.

Okun, M. A., \& George, L. K. (1984). Physician-and self-ratings of health, neuroticism and subjective wellbeing among men and women. Personality and Individual Differences, 5(5), 533-539.

Schimmel, J. (2009). Development as happiness: the subjective perception of happiness and undp's analysis of poverty, wealth and development. Journal of Happiness Studies, 10(1), 93-111.

Sohn, K. (2010). Considering Happiness for Economic Development: Determinants of Happiness in Indonesia. Seoul.

Stevenson, B., \& Wolfers, J. (2009). The paradox of declining female happiness. National Bureau: National Bureau of Economic Research.

Stone, A. A., \& Mackie, C. E. (2013). Subjective well-being: Measuring happiness, suffering, and other dimensions of experience. New York: National Academies Press.

Waldron, S. (2010). Measuring subjective wellbeing in the UK. New Port: Office for National Statistics. 